\title{
Signal Transducer and Activator of Transcription 6
}

National Cancer Institute

\section{Source}

National Cancer Institute. Signal Transducer and Activator of Transcription 6. NCI

Thesaurus. Code C28670.

Signal transducer and activator of transcription 6 (847 aa, $\sim 94 \mathrm{kDa}$ ) is encoded by the human STAT 6 gene. This protein is involved in the modulation of both gene expression and signal transduction. 